\title{
DIE METODES VAN VERSTAAN EN VERKLAAR IN DIE WETENSKAPSTEORIE
}

\author{
A. von L. Pretorius \\ Witwatersrandse Tegnikon, Johannesburg
}

Ten aanvang moet ons duidelikheid kry oor die terme "verstaan" en "verklaar". Soos ons dit hier gaan gebruik, het hierdie terme spesifieke tegniese betekenisse, wat egter wel gebaseer is op, en tot 'n mate verband hou met die alledaagse betekenisse. Wat die presiese aard van die tegniese konnotasies is, hoop ons om algaande te laat duidelik word.

Die metodes waarna ons verwys, staan in die wetenskapsteorie teenoor mekaar. Die feit is dat hul slegs aanduidings is van iets baie meer massief en dieperliggend, naamlik twee teengestelde benaderings tot die wetenskap as sodanig. Laasgenoemde benaderings hang saam met die moontlike antwoorde op die fundamentele vraag: Wat is wetenskap en hoe moet dit beoefen word? In resente literatuur word hierdie verskil dikwels aangedui as die kloof wat 'n "Aristoteliese" benadering tot die wetenskap skei van 'n "Galileïese". Dit moet egter dadelik genoem word dat die metodes van verstaan en verklaar nie per se ekwivalent gestel kan word met Aristoteliese en Galileiese wetenskapsbeoefening nie. Daar is egter' $n$ verband en 'n oorvleueling. Eksponente van laasgenoemde twee benaderings voel hulself intuïtief aangetrokke tot die een of die ander van die metodes.

Om die metodes in perspektief te sien, sal dit dus die moeite loon om vlugtig aandag te skenk aan die grondliggende benaderingsverskil. G.H. von Wright dui dic vernaamste verskil tussen Aristoteliese en Galileiese wetenskap sonder meer aan as die verskil tussen teleologie en kousaliteit. Teleologie impliseer ordening en samehang, doelmatigheid en doelgerigtheid, met een woord, finalisme Daarteenoor staan die vorm van kousaliteit waarvan hier sprake is, naamlik 'n deterministiese wetgebondenheid en wetsbeheersde meganisme. In die geskiedenis van die WesEuropese wetenskap is 'n voortdurende penduleswaai tussen hierdie twee antitetiese beskouinge waar te neem. Gedurende die Hellenistiese tyd en die Middeleeue voer die Aristoteliese siening die botoon; met Galileo maak 'n nuwe metode, gebaseer op eksperimentele verifikasie en induktiewe veralgemening, sy verskyning. Omrede die sukses wat dit behaal, veral op die gebied van die eksakte wetenskappe en die tegnologie, behou dit 'n onaangetaste posisie vir drie eeue. Tans is daar egter, volgens Von Wright, 'n swaaibeweging terug; ons merk dit veral in die biologiese wetenskappe - miskien sal dit mettertyd ook 'n uitwerking hê op die menswetenskappe. Die beweging kan nie bestempel word as ' $n$ "terug na Aristoteles" sonder meer nie; dit is eerder "n poging om met behulp van Aristoteliese elemente te ontkom aan die engheid en uitsigloosheid van 'n bloot meganistiese siening.

Die "Methode des Verstehens" is nie skerp omlyn nie, iets wat dit by 'n eerste ontmoeting moeilik maak om 'n geheelbeeld daarvan te vorm. Ons sal dus kortliks die historiese ontwikkeling van die metode volg, om sodoende 'n beter begrip van die samestellende elemente daarvan te kry. Dit kan aanvaar word dat dit sy 
ontstaan vind in die teologiese en historiografiese hermeneutiek. Joachim Wach noem. J.M. Chladenius die grondlegger van die moderne wetenskaplike geskiedskrywing en ook die eerste wetenskapsteoretikus wat "verstaan" as metode omskryf. Met die ontwikkeling van die geesteswetenskappe as geordende studieveld, veral in Duitsland aan die einde van die agtiende en begin negentiende eeue, neem die metode in belangrikheid toe. Hier kan as voorbeeld die naam van Von Ranke genoem word. Vir hom is dit die taak van die historikus "den Sinn jeder Epoche an und für sich zu verstehen, und verstehen zu lehren". As nog is hierdie "verstaan" vir Ranke niks anders nie as empirie, 'n waarneem van gebeure en ont moet van karakters in openhartige onbevooroordeeldheid nie. Die doel van so 'n verstaan is om die dinge te sien soos wat hul in werklikheid is, "das Wesen der individuellen Erscheinungen zu erfassen". Ranke is nie professionele filosoof nie; inderwaarheid staan hy afsydig teenoor wysgerige vrae in sy vakgebied. Tog kom hier vrae in sig wat noop tot wysgerige besinning - om 'n voorbeeld te noem: Wat is die wese van so 'n "individuelle Erscheinung"?

Droysen se denke oor die aard van die wetenskap bring ons by die teenstelling natuurwetenskap/geesteswetenskap. Hy sien naamlik in die wetenskappe 'n di ie- deling van filosofiese, fisiese en historiese metodes. Hierdie drie metodes het onderskeidelik tot taak om te ken, te verklaar en te verstaan. Sy taak, en die taak van die geesteswetenskaplike van sy tyd, sien hy dan vernaamlik daarin om die studie van die mens en sy aard, geskiedenis en kultuur af te skerm teenoor die opkomende positiwisme en materialisme van die tweede helfte van die negentiende eeu.

Met Wilhelm Dilthey kry die metode van "verstaan" finale en wysgerige beslag. Volgens hom is dit by uitnemendheid die metode van die geesteswetenskappe en geskiedenis, Die metode fundeer in die werkinge van die gees. Dilthey leun hier swaar op Hegel, en veral laasgenoemde se uiteensetting van die aard van die "objektiewe gees". Vir Dilthey, anders as vir Hegel egter, is objektiewe gees nie 'n metafisiese entiteit wat sigself in die wêreld manifesteer nie; dit is niks anders nie as die wyse waarop die mens handelend en skeppend in die wêreld eksisteer. Dieselfde gees wat in die innerlike van die mens leef, word teruggevind in die dinge wat die mens rondom hom tot stand bring. Om 'n voorbeeld te noem: Die bome in die park is weliswaar fisiese objekte - die seleksie en ordening van die bome egter, is ' $\mathrm{n}$ geestelike aktiwiteit van die mens. Die leefwèreld van die mens is die wêreld van die gees; die mens verstaan hierdie wêreld, en omgekeerd verstaan hy homself vanuit hierdie wêreld. Die wêreld word dus verstaan in soverre - maar ook slegs in soverre - as wat dit "menschenähnlich" is. Hoe word die geestelike in die wêreld herken? Ons het dit reeds implisiet gestel in die gegewe voorbeeld: Die verstaan van die wêreld en die dinge in die wêreld is onlosmaaklik verbind aan ordening. aan die tot stand bring - of herken - van samehange en strukture. Kortom - die ontdekking van sinvolheid en betekenis ("Bedeutung"). En dit bring ons midde-in die Aristoteliese wetenskapsbeoefening. Dit is duidelik waarom so ' $n$ wetenskapsbeoefening as "idealisties" aangedui kan word. 
Die metode van "verklaar" het sy oorsprong in beide die Humese kousaliteitsopvatting en Comte se positiwisme. Indien die begrip van 'n oorsaak gestroop word van die idee van "noodsaaklikheid", soos deur Hume gedoen, word algou besef dat iets benodig word om die leemte te vul. Comte vervang die behoefte aan "noodsaaklikheid" met die gedagte van "wetmatigheid". In die "Discours" stel hy dit dat die positiwistiese wetenskap sal poog om "l'inacessible determination des causes" te laat vaar ten gunste van "la simple recherche des lois". Die betekenis hiervan is dat die wêreld - en dit sluit die mens in - begryp en verklaar kan word deur 'n studie te maak van die wette wat dit beheers. Hierdie benadering bring 'n hele samehang van konsekwensies in sig. Die eerste is die opvatting omtrent ' $n$ algemene wetmatigheid, iets wat ons weer by die Hempelse model van verklaring sal teëkom. Dit het op sy beurt ' $n$ verdere konsekwensie daarin dat dit 'n metodemonisme noodsaaklik maak, om die rede dat indien die fisiese proseswêreld en die menslike leefwêreld deur dieselfde almagtige wetmatigheid beheers word, word enige wetenskaplike metodedualisme sinloos. In laase instansie lei so'n monisme dan tot die reduseer van die wetenskap, insluitende natuurlik die menswetenskappe, tot 'n fisikalisme, dit wil sê die uitgangspunt dat die fisiese wetenskappe nie slegs die model daarstel van wat wetenskap behoort te wees nie, maar in ekstreme vorm selfs die standpunt dat alle emotiewe en normatiewe aspekte van menslike lewe sinvol bestudeer kan word slegs wanneer dit herlei kan (en behoort te) word na bloot fisiese prosesse. Hierdie samehang van idees kry volledig gestalte in die wetenskapsleer van die "Wiener Kreis", en by name in die denke van Carnap en Neurath.

Die deduktief-nomologiese verklaringsmodel van Carl Hempel is nie soseer ' omvangryke en uitgewerkte metode nie; dit is meer op die aard van 'n skema. Miskien juis omrede die beperkte omvang daarvan is dit in meer detail ontwikkel as die metode van verstaan. Volgens die Hempelse model bestaan ' $n$ verklaring of "eksplanans", vir'n sekere "eksplanandum", uit twee dele te wete 'n algemene wet of stel wette, en 'n antesedente toestand of toestande. 'n Algemene wet is ' $n$ wet met universele geldigheid, terwyl ' $n$ antesedente toestand 'n situasie is wat op 'n sekere tyd en plek heers. Om iets te verklaar, beteken om een of ander wet dan in verband te bring met 'n sekere konkrete toestand waaruit laasgenoemde dan noodwendig moet voortvloei. Hierdie skema toon daarin ooreenkoms met die Aristoteliese sillogisme dat die Hempelse eksplanans beskou kan word as bestaande uit twee premisse, wat noodwendigerwyse moet lei tot die konsekwens. Hierdie analogie gee aanleiding tot die adjektief "deduktief" in die benaming van die model. Omdat die wetmatigheidsaspek inherent is aan die model, gebruik William Dray dan ook daarvoor die benaming "covering law"-verklaring.

Aangesien die eksplanandum noodwendig moet volg uit die eksplanans, sou dit teoreties ook daaruit voorspel kon word. Hierin lê dan die ideaal van hierdie model, naamlik om nie slegs te verklaar nie, maar uiteindelik ook te voorspel. Die voorspellingstrewe vloei voort uit die beheersingsmotief; hiermee is ons dan terug by Comte se wetenskapsteorie.

Die lynreg-teenoorstaande uitgangspunte en werkwyses van die metodes van "verklaar" en "verstaan" word ten beste geïllustreer deur as voorbeeld te neem 'n 
dissipline waarin die metodestryd steeds nog 'n brandende en aktuele saak bly naamlik die geskiedkunde. Vir die idealisme van die verstaanmetode is die mees blywende verslag van menslike handeling en bemoeienis met die wêreld te vind in die geskiedenis; die geskiedskrywing is dus by uitnemendheid die wetenskap wat die deur open tot die werklike verstaan van die mens. Uit die aard van die saak is die eiesoortigheid van die geskiedkunde dus een van die vernaamste eienskappe daarvan. Die geskiedkunde mag nie oor 'n gemene noemer gebring word met die "eksakte" wetenskappe nie. Vir die metode van verklaar is die geskiedkunde glad geen wetenskap nie - altans nie soos dit tans bedryf word nie. Die moontlikheid bestaan egter dat dit 'n wetenskap kan word wat betroubare - en selfs voorspelbare - resultate bied. Die voorwaarde hiervoor is egter die toepassing van korrekte metodes, waaronder dié van die erkenning van die wetbeheersheid van menslike gedrag wat wesenlik, soos Zilsel dit stel, nie veel verskil van die prosesse van die fisiese wêreld nie.

Wat moet nou ons finale uitspraak in hierdie saak wees? Na aanleiding van die voorbeeld van die stryd rondom die historiografiese metode kan ons hierdie vraag probeer beantwoord. Ten aanvang kan dit onomwonde, en sonder vrees om in ' idealistiese metafisika te verval, gekonstateer word dat die mens leef in 'n wêreld van norme en waardes, wat gevind en realiseer word in sy regspleging, sosiale saamwees, ekonomiese, kulturele, religieuse en ander lewenskringe. En vir die wetenskaplike bestudering van hierdie terreine is die metodes van die eksakte ("natuur"-) wetenskappe net nie voldoende nie. Om te sê dat hierdie metodes nie voldoende is nie, is egter nie om te beweer dat hul geen nut hier het nie, want die menslike leefwêreld fundeer wel deeglik in die subnormatiewe, die wêreld van fisiese objekte en prosesse. Die twee wêrelde is komplementerend; die geskiedenis van menslike handelinge is nie bloot ' $n$ beskrywing van die manifestasie van Gees in die wêreld nie, maar dit is ook aan die ander kant nie slegs die resultaat van sekere fisiese en hiologiese wette nie. Die mens kan slegs ten volle verstaan - en verklaar - word, wanneer hy in geheel gesien word, en wel binne die Skepping waartoe hy behoort.

\section{BIBLIOGRAFIE}

BOLLNOW, O.F. 1949. Das Verstehen; drei Aufsätze zur Theorie der Geisteswissenschaften. Mainz. Verlag Kirchheim.

COMTE, A. 1956. Discours sur L'Esprit Positif. Hamburg, Felix Meiner Verlag.

DILTHEY, W. 1958-1962. Gesammelte Schriften, Band 7. Stuttgart, B.G. Teubner.

DRAY, W. 1966. Laws and explanation in history. London, Oxford University Press.

FEIGL, H. 1969. The origin \& spirit of Logical Positivism. (In: The legacy of Logical Positivism. Baltimore, John Hopkins University Press).

HEMPEL, C.G. \& OPPENHEIM, P. 1948. Studies in the logic of explanation. Philosoph!' of Science. Vol. 15.

LENK. H. 1972. Erklărung, Prognose, Planung. Freiburg, Verlag Rombach.

VON WRIGHT, G.H. 1974. Erklăren und Verstehen. Frankfurt, Athenäum Verlag.

WACH, J. 1966. Das Verstehen, Band 3. Hildesheim, Georg Olms Verlag.

ZILSEL, E. 1941. Physics and the problem of historico-sociological laws. Philosophy of Science. Vol. 8. 